\title{
Strategi Membangun Media Daring Melalui Komunikasi Pemasaran Terpadu (Studi Kasus Pada Bertuahpos.com)
}

\author{
Gunawan Saleh \\ Program Studi Ilmu Komunikasi, Universitas Abdurrab \\ Email: gunawan.saleh@univrab.ac.id \\ Prsetia Rahmad \\ Program Studi Ilmu Komunikasi, Universitas Abdurrab
}

\begin{abstract}
Abstrak
Iklan sangat menentukan berkembang atau tidaknya media daring. Untuk itu media daring tidak bisa hanya menulis dan menyebarkan informasi, namun juga harus dapat melakukan komunikasi dalam konteks komunikasi bisnis. Metode dalam penelitian ini adalah deskriptif kualitatif dengan wawancara. Hasil wawancara dengan empat informan, dan disimpulkan bahwa Bertuahpos.com melakukan strategi komunikasi bisnis melalui sosialisasi yang dilakukan dimedia sosial, hal ini dimaksudkan untuk memperkenalkan bertuahpos.com kepada masyarakat.Untuk menjalin komunikasi bisnis yang efektif, bertuahpos.com melakukan coffe morning bersama narasumber. Selain itu Bertuahpos.com melakukan penawaran iklan baik secara langsung maupun tidak langsung seperti melalui proposal penawaran iklan, sehingga dapat meningkatkan target finansial perusahaan lewat iklan yang diperoleh. Bertuahpos.com juga memberikan sarana bagi pembaca untuk menjual produk secara gratis pada konten toko bisnis untuk meningkatkan viewers.
\end{abstract}

Kata kunci : Strategi, Media Daring, Komunikasi Pemasaran Terpadu.

\begin{abstract}
Advertising is determining whether or not this online mass media develops. For that the online mass media can not only write and disseminate information, but also must be able to communicate in the context of business communication. The method in this research is descriptive qualitative with interview. The results of interviews with four informants, and concluded that Bertuahpos.com doing business communication strategy through socialization conducted social dimedia, it is intended to introduce bertuahpos.com to masyarakat.Untuk establish effective business communication, bertuahpos.com coffe morning with resource persons. In addition, Bertuahpos.com offers advertisements either directly or indirectly through advertising offer proposals, thereby increasing the company's financial objectives through the advertisements it receives. Bertuahpos.com also provides a means for readers to sell products for free on business store content to enhance viewers.
\end{abstract}

Keywords: Strategy, Online Media, Integrated Marketing Communications. 


\section{PENDAHULUAN}

Perkembangan cyber journalism terus mengalami peningkatan yang signifikan. Hal ini dapat dilihat dari terus menjamurnya media daring di Indonesia, termasuk di Kota Pekanbaru. Jumlah media daring di Pekanbaru sudah mencapai puluhan, dan terus mengalami peningkatan. Hal ini dikarenakan cost yang dibutuhkan untuk mendirikan media daring tidak sebesar media cetak (surat kabar). Media daring tidak membutuhkan biaya yang besar untuk beroperasi. Selain itu, perkembangan dunia digital juga turus mendukung perkembangan media daring. Masyarakat dapat mengakses berita kapan saja dan dimana saja, hanya melalui perangkat komputer atau smart phone.

Marshall McLuhan dalam bukunya Understanding Media mengatakan bahwa media adalah The Exstension of Men (media itu perluasan manusia). Dengan kata lain, media menjadi 'kepanjangan' tangan manusia. Media dengan jangkauan yang dimilikinya akan meluaskan banyak hal pada diri manusia, lembaga atau institusi pemerintah. Namun, tidak semua media dengan dapat berkembang dengan baik. Iklan sangat menentukan berkembang atau tidaknya media daring ini. Jika media daring tersebut telah memiliki kredibilitas yang baik di masyarakat dan dikunjungi oleh banyak viewers maka akan semakin mudah bagi media daring tersebut untuk mendapatkan sponsor atau iklan guna menunjang biaya operasinalnya. Untuk itu, media daring tidak bisa hanya menulis dan menyebarkan informasi, tapi juga harus dapat melakukan komunikasi pemasaran. Untuk mendapatkan sponsor atau iklan tentu media tersebut harus aktif mengkomunikasikan produk-produknya. Hal ini penting karena walaupun media sudah menjalankan fungsi-fungsi promosi dan komunikasi, namun menjalankan komunikasi bisnis secara khusus tetap harus dijalankan untuk mendapatkan sponsor dan iklan.

Media daring tidak seperti media cetak yang bisa menjual koran setiap hari, namun hanya mengandalkan pada berita atau informasi yang diberikan kepada masyarakat. Untuk itu selain informasi yang mendukung, juga harus ditunjang dengan keterampilan komunikasi bisnis, karena sejatinya apapun jenis usaha yang dilakukan, praktik komunikasi bisnis tidak bisa dihindari, walaupun usaha dalam bidang media online sekalipun.

Seperti halnya PT. Citra Media Bertuah atau yang lebih kita kenal dengan nama Bertuahpos.com. Media daring yang terkenal sejak pemberitaan tentang pemerintahan Mantan Gubernur Annas Ma'mun ini terus mengalami perkembangan ditengah meningkatknya persaingan media daring. Sejak pemberitaannya mencuat kepermukaan, media ini menjadi sorotan kala itu. Dengan mengusung referensi utama ekonomi bisnis masyarakat Indonesia terutama Riau, media ini hadir dengan berbagai pilihan mulai dari finance, news,travelling, public service sampai pada teknologi.

Saat ini media daring bertuahpos.com memiliki pembaca yang cukup tinggi dibanding dengan media daring lainnya, yaitu rata-rata mencapai 20.000 pengunjung setiap hari, (sumber, riki ariyanto, reporter bertuahpos.com). Tentu saja hal ini tidak akan terjadi tanpa 
adanya komunikasi bisnis yang baik yang diterapkan oleh bertuahpos.com itu sendiri. Untuk itu, dari latar belakang di atas, penulis tertarik untuk meneliti tentang "Strategi Membangun Media Daring Melalui Komunikasi Bisnis (Studi Kasus Pada Bertuahpos.com)."

Berangkat dari Latar Belakang diatas, masalah pokok penelitiannya adalah bagaimana strategi membangun media daring melalui komunikasi bisnis (studi kasus pada Bertuahpos.com). Dengan menjawab pertanyaan ini, diharapkan akan memberikan gambaran dan informasi kepada pihak-pihak terkait khususnya lulusan komunikasi mengenai penerapan komuniksi bisnis pada media daring sebagai tambahan pengetahuan dan pengalaman bagi peneliti guna memperdalam ilmu dibidang kehumasan dan sumbangsih pemikiran kepada media online betapa pentingnya penerapan komunikasi bisnis untuk menunjang kinerja perusahaan, juga sebagai alat untuk meningkatkan jumlah sponsor dan iklan.

Sejauh ini, penelitian yang berkaitan dengan internet (world wide web ) atau tentang media online telah mengalami perkembangan yang signifikan. Salah satu penelitian yang dilakukan oleh seorang mahasiswa pascasarjana di Universitas of Texas, Myung-ho Yoon (1998), yang meneliti tentang pengaruh situs - situs media online di Korea. Penelitian tersebut menunjukkan bahwa sifat media, yaitu kesiapan (mengetahui dengan segera), dan stabilitas (mendapakan berita kapan saja mereka inginkan) adalahpaling penting bagi pengguna situs - situs media online.Untuk mempelajari sesuatu adalah alasan terpenting dalam kategori situasi paparan. Dalam hal daya akses, ekonomis dan faktor kesenangan merupakan alasan yang dianggap penting dalam pengaksesan situs berita online. (neiu.edu/academics).

Selain itu, penelitian tentang media daring juga pernah dilakukan oleh Muhammad Rifefan (2014), mahasiswa ilmu komunikasi Universitas Islam Negeri Sunan Kalijaga. Rifefan meneliti tentang penggunaan media online dalam memenuhi kebutuhan informasi akademis. Dimana hasil dari penelitian ini adalah bahwa media online digunakan untuk memenuhi kebutuhan informasi dan menjadi sebuah alternatif yang mengesankan dalam berbagai hal, seperti kecepatan dan keragaman informasi yang didapat.

Media daring itu sendiri didefinisikan sebagai media yang berbasis telekomunikasi dan multimedia (komputer, internet). Di dalamnya, terdapat portal, website, radio daring, TV daring, pers daring, mailing dengan karakteristik masing - masing sesuai dengan kebutuhan dan fasilias yang memungkinkan user memanfaatkan informasi yang ada (Romli \& Syamsul, 2012)

Situs berita merupakan salah satu sub-sistem berbasis daring. Penyebutan media daring di kalangan ahli media cukup beragam. Salah satu desain media daring yang paling unggul diaplikasikan dalam praktik jurnalistik modern adalah situs berita. Situs berita atau portal merupakan sarana informasi. Media daring ini dikarakteristikan sebagai berikut.

a. Kecepatan (aktualitas) informasi

Kejadian atau peristiwa yang terjadi di lapangan langsung di upload kedalam situs web media tanpa harus menunggu hitungan menit, jam atau seperti yang 
terjadi dimedia elektronik atau cetak. Dengan demikian, mempercepat distribusi informasi ke pasar (pengakses) dengan jangkauan global lewat jaringan internet, dan dalam waktu bersamaan. Umumnya, informasi yang ada juga dalam bentuk data atau fakta bukan cerita.

b. Adanya pembaruan (updating) informasi. Informasi disampaikan secara terus menerus. adanya pembaruan (updating) informasi. Berita besifat real time. Hal ini menyebabkan tidak adanya waktu yang diistimewakan (prime time) karena informasi berlangsung terus menerus tanpa putus, hanya tergantung kapan pengguna mau mengaksesnya.

c. Interaktivitas

Salah satu keunggulan media online ini yang membedakan dirinya dengan media lain adalah interaktif. Model komunikasi yang digunakan secara konvensional biasanya bersifat searah (linier) bertolak dari kecenderungan sepihak dari atasan (up-down), sedangkan media online bersifat dua arah, berbagai features yang ada seperti online polling/survei, check e-mail, games merupakan interactive options yang terdapat di media online. Pembaca pun dapat menyampaikan keluhan, tanggapan kebagian redaksi dan bisa langsung direspon.

d. Personalisasi

Pembaca atau pengguna semakin otonom dalam menentukan informasi mana yang ia butuhkan, media online memberikan peluang kepada setiap pembaca hanya mengambil informasi yang relevan baginya dan menghapus informasi yang tidak ia butuhkan. Selektivitas informasi dan sensor berata ditangan pengguna (self control). e. Kapasitas muatan dapat diperbesar Informasi yang termuat bisa dikatakan tanpa batas karena didukung media penyimpanan data yaitu server komputer dan sistem global. Informasi yang pernah disediakan akan tetap tersimpan, kapan saja, dan pembaca dapat mengakses dengan mesin pencari (search engine).

f. Terhubung dengan sumber lain (hyperlink). Setiap data dan informasi yang disajikan dapat dihubungkan dengan sumber lain yang jua berhubungan dengan informasi tersebut, atau disambungkan dengan data yang dimiliki media tersebut atau dari sumber luar. Karakter hyperlink ini juga membuat pengakses bisa berhubungan dengan pengakses lain ketika masuk kesebuah situs media online dan menggunakan fasilitas yang sama dalam media, contohnya chatroom, lewat e-mail, dll.

Untuk membangun media daring terpercaya, diperlukan suatu proses komunikasi Sebagai suatu proses, komunikasi mempunyai persamaan dengan bagaimana seseorang mengekspresikan perasaan, hal-hal yang berlawanan (kontradiktif), yang sama (selaras, serasi), serta meliputi proses menulis, mendengar, dan mempertukarkan informasi. Menurut L. Bovee dan V. Thil (2003: 61) dalam Business Communication Today, proses komunikasi (communication process) terdiri atas enam tahap, yaitu:

1. Pengirim mempunyai suatu ide atau gagasan.

2. Pengirim mengubah ide menjadi suatu pesan.

3. Pengirim menyampaikan pesan.

4. Penerima menerima pesan.

5. Penerima menafsirkan pesan. 
6. Penerima memberi tanggapan dan mengirim umpan balik kepada pengirim.

Sebelum melakukan proses komunikasi, syarat utamanya adalah adanya ide/gagasan. Karena persepsi bersifat unik, ide/gagasan yang disampaikan akan ditafsirkan secara berbeda oleh orang lain. Seorang komunikator harus dapat menyaring hal-hal yang tidak penting/tidak relevan, hal ini biasa disebut dengan abstraksi (abstraction). Ide yang berbentuk abstrak harus dirubah kedalam bentuk pesan. Agar ide dapat diterima dan dimengerti secara sempurna, maka pengirim pesan harus memperhatikan beberapa hal, yaitu subjek (apa yang ingin disampaikan), maksud (tujuan), audiens, gaya personal, dan latar belakang budaya.

Pesan tidak dapat dipahami pihak lain tanpa adanya pemindahan pesan. Hal ini tergantung pada jenis pesan yang disampaikan, kita dapat menggunakan berbagai media komunikasi yang tersedia. Pesan yang diterima adakalanya sempurna, namun tidak jarang hanya sebagian kedil saja. Penafsiran suatu pesan secara teratur bila penerima pesan memahami pesan sebagaimana yang dimaksud oleh pengirim pesan. Sementara itu feedback dapat berfungsi sebagai koreksi bagi pengirim.

Umpan balik memegang peranan penting dalam proses komunikasi, karena ia memberi kemungkinan bagi pengirim untuk menilai efektifitas suatu pesan. Disamping itu, adanya umpan balik dapat menunjukkan adanya fakor-faktor yang menghambat komunikasi, misalnya perbedaan latar belakang, perbedaan penafsiran kata-kata, dan perbedaan reaksi secara emosional. Selain model komunikasi Courtland L.Bovee dan John V.Thil, David K. Berlo dalam Dewi (2007:4) menjelaskan unsur-unsur utama komunikasi terdiri atas SMCR, yaitu (sumber, massage, channel, dan receiver). Disamping itu, terdapat tiga unsur lain yaitu feedback, efek dan lingkungan.

\section{METODE PENELITIAN}

Metode penelitian ini adalah kualitatif. Dimana penelitian kualitatif merupakan jenis penelitian yang menghasilkan penemuan-penemuan yang tidak dapat dicapai dengan mengunakan prosedur statistik atau cara kuantifikasi lainnya (Ruslan, 2003: 202). Denzin dan Lincoln dalam Moleong (2004: 5) menjelaskan bahwa penelitian yang mengunakan latar alamiah dengan maksud menafsirkan fenomena yang terjadi dan dilakukan dengan jalan melibatkan berbagai metode seperti wawancara, pengamatan dan pemanfaatan dokumen. Data akan dikumpulkan dengan menggunakan cara sebagai berikut.

1. Wawancara (interview). Wawancara adalah cara pengumpulan data melalui tanya jawab langsung dengan personel dan untuk mendapatkan data sesuai dengan penelitian. Informan dari pihak tim redaksi, yaitu Muhammad Junaidi, yang merupakan pimpinan redaksi sekaligus pimpinan perusahaan. Ini dikarenakan yang bersangkuran adalah pendiri dari bertuahpos.com. Informan dari pihak wartawan/reporter, yaitu Riki Ariyanto, yang merupakan wartawan yang pos di pemeritah kota Pekanbaru, dan sudah memulai 
karirnya di bertuahpos.com sejak tahun 2013. Informan dari pihak wartawan, yaitu Melba Fery Fadly, yang merupakan salah satu wartawan/reporter bertuahpos.com. Informan dari bagian marketing dan business development, yaitu $\mathrm{Rr}$ Dian Sari Anjani, yang merupakan staff bagian bisnis dan pemasaran bertuahpos.com

Pengumpulan informasi diawali dari pembicaraan seputar awal mula berdirinya bertuahpos.com, dimana portal daring ini berdiri dari sejak tahun 2012. Namun, baru dikenal oleh masyarakat pada tahun 2013, hal ini dibuktikan dengan bertambahnya beberapa reporter. Seperti diketahui, portal daring memiliki beberapa perbedaan dengan media massa cetak yang telah lebih dulu ada, salah satu hal yang sangat menonjol adalah portal daring tidak memerlukan waktu yang lama untuk menerbitkan sebuah berita, berbeda dengan media cetak yang harus melewati beberapa proses untuk menerbitkan sebuah pemberitaan.

2. Observasi. Observasi adalah metode pengumpulan data yang digunakan untuk menghimpun data penelitian melalui pengamatan dan penginderaan (Bungin, 2008: 115), sedangkan yang akan diobservasi adalah strategi membangun media daring melalui komunikasi bisnis (studi kasus pada bertuahpos.com).

3. Dokumentasi. Dokumentasi adalah metode yang digunakan untuk menelusuri data historis (Bungin, 2008: 121). Dalam dokumentasi ini, peneliti memanfaatkan arsip-arsip dan dokumen perusahaan.

Untuk menganalisis data, digunakan metode analisis deskriptif kualitatif. Sesuai dengan pendekatan yang digunakan, yaitu kualitatif deskriftif sehingga data yang berhasil dikumpulkan tidak digunakan uji statistik, melainkan non statistik sesuai dengan penelitian yang bersifat kualitatif. Denzin dan Lincoln menyatakan bahwa penelitian kualitatif adalah Pada analisis data kualitatif, kata-kata dibangun dari hasil wawancara atau pengamatan terhadap data yang dibutuhkan untuk dideskripsikan dan dirangkum (Patilima, 2005: 88).

Pada penelitian ini, penulis mengunakan teknik analisis data interaktif Miles dan Huberman seperti yang terlihat pada gambar 1 berikut. 


\section{Gambar 2}

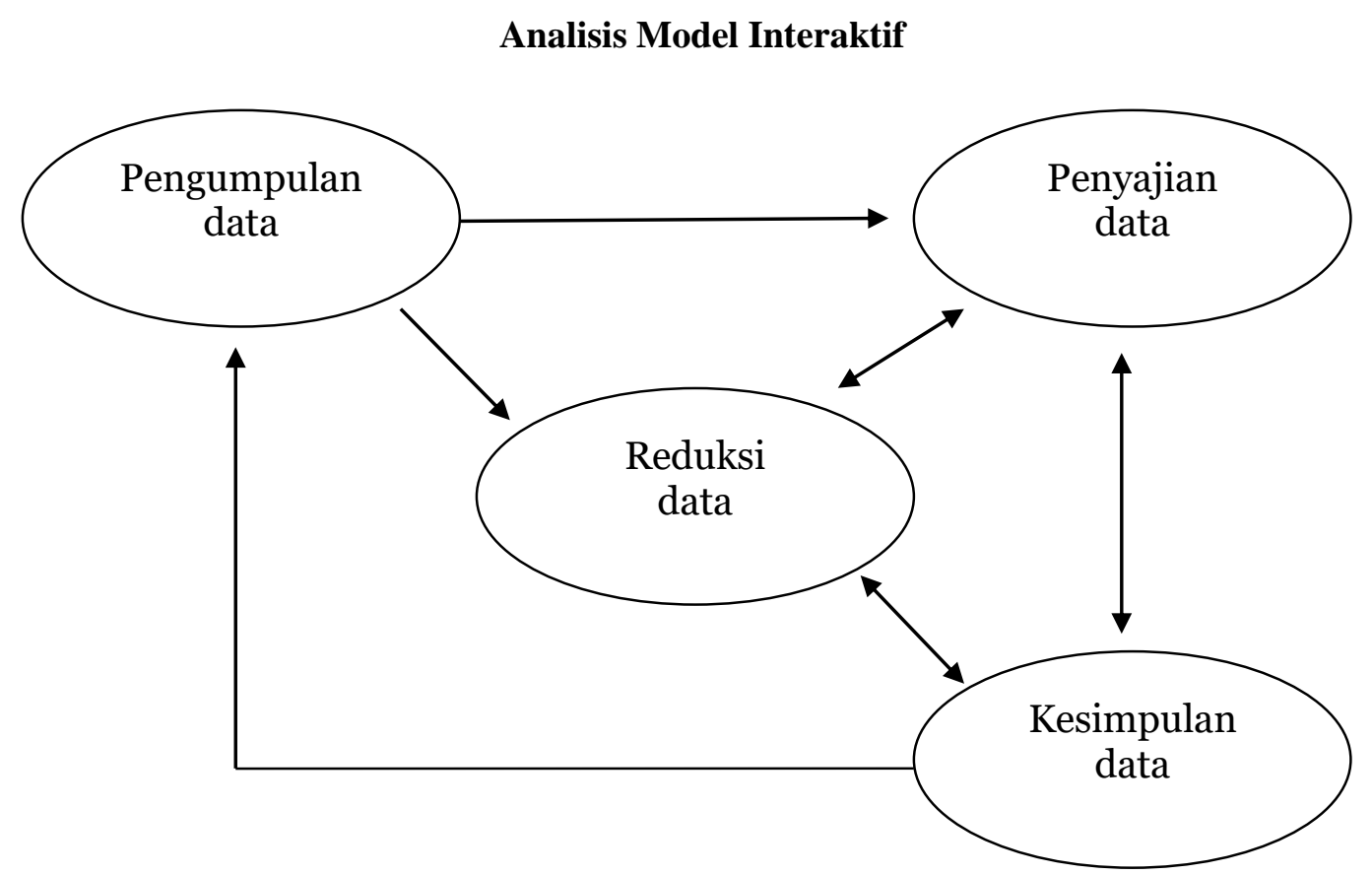

Sumber: Miles dan Huberman dalam (Patilima, 2005: 100)

Teknik analisis data pada model interkatif menurut Miles dan Huberman ini menunjukan adanya sifat interaktif antara kolektif data atau pengumpulan data. Analisis data yang dimaksud yaitu reduksi data, penyajian data dan verifikasi atau penarik kesimpulan. Reduksi data adalah mengelola data dengan bentuk analisis yang menajamkan, menggolongkan, mengarahkan, membuang data yang tidak diperlukan serta mengorganisir data tersebut. Dengan mengorganisir data maka dapat dengan mudah menyajikakn atau memaparkan data-data yang diperlukan yang disimpulkan dengan cara induktif pada penelitian, dengan demikian dapat ditarik kesimpulan atau verifikasi dalam menganalisis data penelitian (Patilima, 2005: 99).

\section{ANALISIS DAN PEMBAHASAN}

Bertuahpos.com merupakan salah satu portal berita daring yang hadir di Pekanbaru.Hadir sejak 2012, bertuahpos.com semakin berkembang dan memiliki pasar yang baik. Portal daring yang dinaungi oleh PT. Citra Media Bertuah merupakan perusahaan media dan komunikasi (citra media bertuah) yang salah satu bidang kelola utama ialah media daring, portal ekonomi dan bisnis.

Portal daring ini hadir untuk segmen pembaca Indonesia khususnya untuk wilayah Riau - Sumatera dan sekitarnya. Untuk memenuhi harapan tersebut, hampir $75 \%$ konten media memfokuskan pada dunia ekonomi dan bisnis seperti finance, market and shoping, travelling, retail dan SMEs, property, lifestyle, profil UKM, good shopper, konsultasi bisnis, starbiz, kolom bisnis, public service, otomotif, teknologi, dan beberapa fitur lainnya. Selebihnya, berupa informasi 
penting yang bersifat umum tentang kondisi Riau terkini maupun nasional. Portal daring ini berharap dapat memjadi referensi utama ekonomi bisnis masyarakat Indonesia terutama Riau.Dengan slogan smart thinking and actions serta portal berita dan bisnis, bertuahpos.com terus mengembangkan sayapnya di industri portal daring yang kini semakin marak di Indonesia, khusunya wilayah Riau.

Portal daring memiliki beberapa perbedaan dengan media massa cetak yang telah lebih dulu ada. Salah satu hal yang sangat menonjol adalah portal daring tidak memerlukan waktu yang lama untuk menerbitkan sebuah berita. Ini berbeda dengan media cetak yang harus melewati beberapa proses untuk menerbitkan sebuah pemberitaan. Untuk itu, jika bertuahpos baru eksis di 2013, dan ditandai dengan bertambahnya jumlah reporter, ini dikarenakan portal daring tidak perlu atau tidak harus memiliki banyak karyawan.

Bertuahpos.com memiliki beberapa konten yang dapat diakses oleh masyarakat, berita - berita yang mendominasi adalah berita ekonomi dan bisnis. Adapun beberapa konten yang dimiliki oleh bertuahpos.com adalah sebagai berikut.

a. Konten traveling, yang memuat berita seputar jalan - jalan, perhotelan, maskapai dan destinasi wisata.

b. Konten berita terkini yang memuat tentang peristiwa yang sedang hits atau baru terjadi. Skalanya bisa lokal atau nasional. Sementara konten internasional mencakup pemberitaan yang sedang terjadi diluar negeri. c. Konten berita foto, konspenya berita namun teks lebih sedikit dan foto lebih banyak.

d. Konten toko bisnis, yaitu rubrik tempat dimana pembaca bisa mengirim barang - barang yang ingin dijual dan hal ini pembaca tidak dikenakan biaya / gratis.

e. Konten otomotif, berisi rubrik yang membicarakan seputar otomotif baik roda dua dan empat.

f. Konten teknologi, berisi tentang pemberitaan tren teknologi terbaru.

g. Konten politik hukum berisi tentang pemberitaan politik, saat ini fukus pada pilkada serentak tahun 2017, juga memuat berita - berita yang menyangkut persoalan hukum.

h. Konten resensi pilihan, isinya tentang resensi - resensi dari buku bisnis pilihan juga film.

i. Konten bisnis, yaitu konten yang berisi berita - berita yang soft atau inspiratif untuk berbisnis. Sifatnya lebih banyak untuk lingkup lokal.

j. Konten properti, yaitu konten yang berisi berita seputar perumahan, apartemen, dan property lainnya serta tips dan panduan dalam membeli dan memelihara properti.

$\mathrm{k}$. Konten market dan shopping, berisi seputar diskon - diskon, trend fashion, dan penawaran produk terbaru.

1. Konten finance, berisi berita seputar keuangan, perbankan, perusahaan finance, dan emas.

m. Konten inspirasi - story, yang berisi tentang kisah - kisah inspiratif dari orang - orang dalam mencapai karirnya. 
Dari konten - konten tersebut, pembaca dapat memilih informasi mana yang mereka butuhkan.Karena portal bertuahpos.com merupakan portal daring yang menitikberatkan pemberitaannya pada berita ekonomi dan bisnis, maka banyak konten - konten yang mewakili informasi seputar ekonomi dan bisnis, seperti finance, market and shopping, property, dll.

Secara keseluruhan, strategi komunikasi bisnis yang dilakukan oleh bertuahpos.com untuk mengembangkan dan menjadikan bertuahpos.com tetap berjalan dengan baik adalah sebagai berikut.

1. Melakukan sosialisasi di media sosial tentang portal berita daring bertuahpos.com, hal ini dimaksudkan untuk memperkenalkan bertuahpos kepada masyarakat yang sering mengakses berita di portal media online, semakin banyak masyarakat yang mengenal bertuahpos maka diharapkan pengunjung portal berita daring bertuahpos juga semakin meningkat.

2. Melakukan agenda coffe morning, hal ini yang mungkin tidak terjadi di situs berita daring yang lain. Coffe morning merupakan kegiatan rutin yang dilakukan di bertuahpos.com, hal ini dimaksudkan untuk meningkatkan hubungan baik dengan narasumber atau stakeholder eksternal. Narasumber akan merasa menjadi bagian dari bertuahpos.com dan hal ini akan meningkatkan hubungan baik antara narasumber dan bertuahpos itu sendiri.

3. Melakukan penawaran - penawaran iklan kepada narasumber potensial, hal ini biasanya dilakukan oleh para reporter/wartawan. Ketika dalam proses peliputan dan didapatkan narasumber potensial, maka reporter akan mencoba untuk melakukan penawaran iklan yang akhirnya akan di "eksekusi" oleh pihak marketing iklan.

4. Melakukan penawaran - penawaran iklan secara langsung kepada pihak eksternal yang dilakukan oleh marketing iklan baik secara verbal atau melalui proposal penawaran yang telah disusun sebelumnya.

5. Melakukan strategi komunikasi secara langsung dengan pembaca, hal ini dapat ditemukan pada konten toko bisnis. Pembaca dapat mengirim barang atau produk yang akan dijual, dan tanpa dikenakan biaya. Dari hal ini, diharapkan akan lebih meningkatkan jumlah pengunjung yang pada akhirnya akan meningkatkan jumlah iklan.

Dari beberapa strategi yang dijalankan oleh bertuahpos.com, kita dapat mengetahui bahwa bertuahpos.com telah melakukan proses komunikasi bisnis, khususnya untuk stakeholder eksternal. Komunikasi bisnis yang dijalankan baik secara verbal atau nonverbal berjalan dengan baik.

Melakukan sosialisasi sampai pada penawaran iklan dan advetorial dilakukan untuk mengejar target finansial perusahaan. Ini karena bagaimanapun "nyawa" dari usaha dibagian media massa khususnya portal berita daring adalah iklan. Semakin banyak iklan pada portal berita tersebut, maka portal situs berita tersebut akan semakin kuat dan dikenal oleh pembaca. Tentu saja, ini dimaksudkan untuk tidak menggangu inti tujuan portal situs berita itu sendiri, dimana berita yang 
diterbitkan harus tetap mengikuti kaidah jurnalistik.

Strategi coffe morning adalah salah satu strategi yang ampuh untuk meningkatkan hubungan baik dengan narasumber. Ketika terjadi proses komunikasi bisnis secara langsung, tapi tetap dilakukan dengan santai dan ringan akan menambah ikatan yang kuat antara narasumber dan bertuahpos.com. Dengan demikian, diharapkan narasumber akan merasa menjadi bagian dari bertuahpos, dan, pada akhirnya, perusahaan akan dapat memenuhi target finansial dari bagian iklan. Komunikasi bisnis mutlak diperlukan walaupun industri media massa adalah usaha publisitas. Komunikasi bisnis tetap harus dilakukan untuk mendapatkan dukungan dari pihak internal dan eksternal sehingga akan terjalin kerjasama yang baik dengan semua pihak yang terkait, baik dengan karyawan ataupun dengan pihak eksternal, yaitu narasumber dan pihak yang memasang iklan di bertuahpos.com.

\section{PENUTUP}

Dari hasil penelitian dan pembahasan tentang strategi membangun media daring melalui komunikasi bisnis (studi kasus pada bertuahpos.com), dapat peneliti simpulkan sebagai berikut. Pertama, bertuahpos.com melakukan strategi komunikasi bisnis melalui sosialisasi yang dilakukan dimedia sosial, hal ini dimaksudkan untuk memperkenalkan bertuahpos.com kepada masyarakat. Kedua, untuk menjalin komunikasi bisnis yang efektif, bertuahpos.com melakukan coffe morning bersama narasumber. Hal ini bertujuan untuk menjalin hubungan komunikasi bisnis yang efektif secara kelembagaan maupun secara personal. Ketiga, bertuahpos.com melakukan penawaran - penawaran iklan baik secara langsung maupun tidak langsung seperti melalui proposal penawaran iklan. Hal ini dilakukan oleh marketing iklan dan dibantu oleh reporter yang melakukan peliputan, sehingga dapat meningkatkan target finansial perusahaan lewat iklan yang diperoleh. Keempat, untuk meningkatkan jumlah pengunjung, bertuahpos.com memberikan sarana bagi pembaca untuk menjual produk secara gratis pada konten toko bisnis. Hal ini dimaksudkan untuk meningkatkan viewers 


\section{DAFTAR PUSTAKA}

Belch, George E., Belch, Michael A., (2009). Advertising and promotion : An Integrated Marketing Communication Perperctive 8th, New York: McGraw-Hill.

Boove, L. Courtland dan John V.Thill, (2003). Komunikasi bisnis, Buku kedua, edisi bahasa Indonesia, Jakarta: PT. Indeks Kelompok Gramedia.

Bungin, Burhan, (2008). sosiologi komunikasi, teori, paradigma dan diskursus teknologi komunikasi masyarakat, Jakarta: Kencana.

Dewi, Sutrisna, (2007). Komunikasi Bisnis, Yogyakarta: Andi.
Moleong, (2004). Metodologi Kualitatif Edisi Revisi. Bandung: Remaja Rosdakarya.

Patilima, Hamid, (2005). metode penelitian kualiatif, Bandung : Alfabeta.

Rifefan, Muhammad, (2014). Penggunaan Mendia Online dalam Memenuhi Kebutuhan Akademik. (Studi Deskriftif kualitatif pada kalangan Mahasiswa Universitas Negeri di yogyakarta. UIN Sunan Kali Jaga.

M.Romli, Asep Syamsul. 2012. Jurnalistik Online: Panduan Praktis Mengelola Media Online. Bandung. Penerbit Nuansa Cendekia. 
Jurnal komunikasi, Volume 12, Nomor 2, April 2018 